\title{
New array approaches to explore single cells genomes
}

\author{
Evelyne Vanneste ${ }^{1}$, Lilach Bittman ${ }^{1}$, Niels Van der Aa ${ }^{2}{ }^{\text {, Thierry Voet }}{ }^{2}$ and Joris Robert Vermeesch ${ }^{1}$ * \\ 1 Laboratory for Cytogenetics and Genome Research, Center for Human Genetics, Katholieke Universiteit Leuven, Universitair Ziekenhuis Gasthuisberg, Leuven, \\ Belgium \\ ${ }^{2}$ Laboratory for Reproductive Genomics, Center for Human Genetics, Katholieke Universiteit Leuven, Universitair Ziekenhuis Gasthuisberg, Leuven, Belgium
}

Edited by:

Ryan Yuen, The Hospital for Sick

Children, Canada

Reviewed by:

Nathan Treff, Reproductive Medicine

Associates of New Jersey, USA

Joy Delhanty, University College

London, UK

${ }^{*}$ Correspondence:

Joris Robert Vermeesch, Laboratory

for Cytogenetics and Genome

Research, Center for Human

Genetics, Herestraat 49, 3000

Leuven, Belgium.

e-mail: joris.vermeesch@uzleuven.be
Microarray analysis enables the genome-wide detection of copy number variations and the investigation of chromosomal instability. Whereas array techniques have been well established for the analysis of unamplified DNA derived from many cells, it has been more challenging to enable the accurate analysis of single cell genomes. In this review, we provide an overview of single cell DNA amplification techniques, the different array approaches, and discuss their potential applications to study human embryos.

Keywords: single cell, array analysis, BAC array, oligoarray, SNP array, chromosomal instability

\section{INTRODUCTION}

Chromosomal abnormalities are inherent to human in vitro fertilized (IVF) preimplantation embryos. FISH studies on normally developing, good quality cleavage stage embryos from IVF patients have shown that $30-65 \%$ are aneuploid in at least one cell (Iwarsson et al., 1999; Munne et al., 2004). A similar proportion of aneuploidies was detected in embryos derived from normal fertile couples (Rubio et al., 2003; Munne et al., 2004; Baart et al., 2006). However, aneuploid numbers of locus-specific FISH probe signals were in general interpreted as whole-chromosome imbalances thereby neglecting the possibility of structural chromosomal aberrations. It was with the development of metaphase comparative genomic hybridization (CGH) using DOP-amplified single cell DNA that the extent of whole-chromosome imbalances could be probed genome-wide. For the first time also segmental chromosome imbalances were reported in approximately $7-32 \%$ of the embryos (Voullaire et al., 2000, 2002; Wells and Delhanty, 2000; Wilton, 2005; Daphnis et al., 2008; Rius et al., 2011). Mosaicism for whole-chromosome aneuploidies was detected in up to $75 \%$ of human cleavage stage embryos (Wells and Delhanty, 2000; Voullaire et al., 2002). With the advent of array CGH, the resolution for single cell analysis was further increased revealing, in addition to the whole chromosomal imbalances, segmental rearrangements in a large number of embryos (Vanneste et al., 2009a; Voet et al., 2011).

To provide further insights in the origins of this chromosomal instability as well as for many clinical applications single cell array approaches will remain invaluable tools in the coming years. Arrays may complement or replace FISH for preimplantation genetic diagnosis (PGD) and screening (PGS; Alfarawati et al., 2011; Fiorentino et al., 2011; Vanneste et al., 2011). Finally, with the advent of genome-wide single nucleotide polymorphism (SNP) arrays it might also become feasible to use arrays as a tool to perform PGD in embryos to detect Mendelian disorders (Voet et al., 2009; Handyside et al., 2010). In this review, we provide an overview of the different array techniques that have been developed over the last few years and discuss their possible applications to study human embryos.

\section{WHOLE GENOME AMPLIFICATION}

One cell from an embryo contains approximately $6 \mathrm{pg}$ of DNA. Array methodologies require hundreds of nanograms of input DNA. Hence, to determine genome-wide copy number variation within a single cell, whole genome amplification (WGA) is required. WGA approaches can be subdivided into PCR- or non-PCR-based (isothermal) methods.

A number of PCR-based WGA methods have been developed including degenerate oligonucleotide primed PCR (DOP-PCR; Fiegler et al., 2003), primer extension PCR (PEP; Zhang et al., 1992; Sermon et al., 1996), and ligation-mediated PCR (Saunders et al., 1989). All those methods suffer from random amplification artifacts and incomplete coverage of loci which may result in the drop out (ADO) or preferential amplification (PA) of one of both alleles (Spits and Sermon, 2009). Recently, a new generation of PCR-based methods has been developed. Genomeplex (Sigma-Aldrich, St. Louis, MO 63103, USA) and Picoplex/Sureplex (Rubicon Genomics Inc., MI 48108, USA/BlueGnome Ltd., Mill Court, Great Shelford, Cambridge, UK) kits are based upon a semirandom, non-enzymatic fragmentation of genomic DNA followed by the addition of specific adaptor sequences to both ends, forming an in vitro molecular library that can be amplified by PCR utilizing flanking universal priming sites. The size of the DNA fragments ranges from 100 to $1000 \mathrm{bp}$, with a median size of $400 \mathrm{bp}$. Based on the company brochures, an ADO rate of $10 \%$ (Picoplex) to $30 \%$ (Genomeplex) can be expected, which is an improvement over previous PCR-based methods.

Multiple displacement amplification (MDA) is a nonPCR-based isothermal reaction using bacteriophage $\varphi 29$ DNA 
polymerase (Repli-G, Qiagen Inc., Valencia, CA 91355, USA; GenomiPhi, GE Healthcare, Roosendael, The Netherlands). MDA is based on a strand displacement amplification at constant temperature which results in DNA products of high molecular weight (up to $70 \mathrm{~kb}$; Blanco et al., 1989; Spits et al., 2006a). The ADO rate of the single cell amplified loci varies between 0 and $60 \%$ (25.8\% on average), while the $25 \%$ PA rate was found much more stable between individual cells (Spits et al., 2006a,b).

In conclusion, a variety of single cell WGA methods are commercially available but none is producing a linear representation of the original single cell genome. Furthermore the obtained array results may depend significantly on the single cell WGA method used (see below). ADO or the random loss of alleles can result in false-positive copy number calls as well as the over- or underamplification of certain loci in the genome. These amplification artifacts complicate reliable genetic variant deduction from the signals obtained with the single cell WGA-DNA on the microarray platform and require specialized interpretation algorithms.

\section{BAC BASED ARRAY CGH}

Array comparative genomic hybridization (aCGH) enables the detection of gains or losses of DNA in all 24 chromosomes. DNA fragments with known positions in the genome are immobilized on a glass slide. Subsequently, DNA from a test and reference sample are differentially labeled and hybridized onto the slides. Copy number changes are determined by differences in hybridization intensities between test and reference DNA. The resolution of the array depends on the size of the probes and the distance between the probes in the genome. With bacterial artificial chromosomal (BAC) based aCGH, BAC DNA fragments are immobilized on a glass surface. Each clone contains a known chromosomal locus of about 100-300 kb (Oostlander et al., 2004). Besides the homemade BAC arrays provided by several laboratories (Le Caignec et al., 2006; Fiegler et al., 2007) at least two BAC arrays are currently commercially available: (1) the constitutional Chip 4.0 (Perkin Elmer) is comprised of approximately 5000 BAC clones and thereby a theoretical resolution of $\sim 600 \mathrm{~kb}$ is achieved. (2) The 24Sure BAC array (Blue Gnome Ltd., Mill Court, Great Shelford, Cambridge, UK) contains 3000 clones spaced $1 \mathrm{Mb}$ apart across the genome. Both commercial platforms have the potential to enable the detection of whole-chromosome aneuploidies in single cells in a $24-\mathrm{h}$ protocol as required in preimplantation genetic testing and provide custom software tools for copy number variation calling.

\section{VALIDATION OF BAC ARRAYS}

Le Caignec et al. (2006) validated a strategy that combined GenomiPhi MDA amplification and a home-made $1 \mathrm{Mb}$ resolution BAC array for single cell analysis. By averaging all intensity ratios per chromosome across multiple single cell experiments the chromosome-specific threshold for variation was determined. Subsequently, they demonstrated the accurate detection of trisomy $13,18,21$ and monosomy $\mathrm{X}$ in different aneuploid fibroblast lines by chromosome average signals that surpass the chromosomespecific threshold (Le Caignec et al., 2006). By applying an optimized version of the amplification method (GenomiPhiV2) and a new algorithm the resolution to detect de novo imbalances was improved to $10 \mathrm{Mb}$, when combined with SNP-array technology
(Vanneste et al., 2009a; Konings et al., 2012). The mixture model that was used not only allowed the calculation of BAC-probe specific copy number probabilities, but also provided a quality assessment allowing the exclusion of un-interpretable single cell WGA-samples (Vanneste et al., 2009a; Konings et al., 2012). Fiegler et al. (2007) developed a home-made tilling BAC array (26,574 clones) which enabled both the detection of aneuploidies and a de novo deletion of $8.3 \mathrm{Mb}$ in GenomePlex amplified HCT116 single cells. To detect segmental imbalances, the average intensity ratio across 10 clones was calculated for each chromosome and plotted against the midpoint position of the 10 clones used for analysis. Each averaged data point was then further normalized. Substantial gains and losses comprised at least three consecutive data points 1.5 times above or below the estimate of the experimental variability. Cells from a renal carcinoma, a colorectal tumor, a trisomy 21, and from a Prader-Willi microdeletion cell line were used for validation. A false-negative rate of 3.0\% was reported, while the false-positive rate was estimated between 2 and 3\% (Fiegler et al., 2007). Gutierrez-Mateo et al. (2011) used the 24Sure BAC array (Blue Gnome Ltd., Mill Court, Great Shelford, Cambridge, UK) following Sureplex amplification for cleavage stage embryo genome copy number profiling. However, a thorough validation is lacking. Sensitivity and specificity of single cell DNA copy number typing must be evaluated using a set of cell lines with known DNAimbalances as exemplified by Fiegler et al. (2006), Vermeesch et al. (2007), Vanneste et al. (2009a), and Konings et al. (2012).

\section{CLINICAL USE OF BAC ARRAYS}

The first use of BAC aCGH (following GenomiPhiV2 WGA amplification) in PGD was for the selection of unbalanced chromosomes in embryos derived from a patient carrying a complex chromosomal rearrangement (Vanneste et al., 2011). Based on the analysis of 16 embryos, the sensitivity was $100 \%$, while the specificity was 89\% (Vanneste et al., 2011). At the same time, Alfarawati et al. (2011) described the first clinical application of BAC array-based screening applied to polar bodies, blastomeres, and trophectoderm cells from patients carrying chromosome rearrangements. They simultaneously screened for unbalanced translocation derivatives and aneuploidy of all 24 chromosomes. They used the Sureplex WGA together with the 24sure Version 2.0 or Cytochip Version 3.0 BlueGnome arrays (BlueGnome Ltd., Mill Court, Great Shelford, Cambridge, UK). A total of 16 couples received genetic diagnosis of their embryos in 20 cycles (Alfarawati et al., 2011). The reported diagnostic efficiency was 91.5\% (Alfarawati et al., 2011). Fiorentino et al. (2011) used the same set-up and technology in cleavage stage embryos. Finally, Fishel et al. (2010) reported the birth of the first baby after genome-wide aneuploidy screening using single cell microarray technology and polar body biopsy. Overall, those studies lack validation (Fishel et al., 2010; Alfarawati et al., 2011; Fiorentino et al., 2011).

\section{OLIGONUCLEOTIDE ARRAYS}

The oligonucleotide aCGH procedure is similar to that of $\mathrm{BAC}$ arrays. The first arrays contained 44.000 (Agilent Technologies, Inc., Santa Clara, CA, USA) to 72.000 oligo probes (Nimblegen, Roche NimbleGen Systems, Reykjavik, Iceland), while the latest contain 1-2.1 million targets respectively. Oligonucleotide 
probes contain between 45 and 85 nucleotides. The higher probe density allows a higher resolution for copy number evaluation. Moreover, oligonucleotide array construction tends to have a better reproducibility and less batch-to-batch variation compared to BAC arrays (Shearer et al., 2007). The main disadvantage for the detection of (single cell) chromosomal imbalances is the significant noise that becomes more obvious due to the random WGA artifacts and the higher probe density (Geigl et al., 2009).

\section{VALIDATION OF OLIGO ARRAYS}

Geigl et al. (2009) performed GenomePlex amplified single cell analyses on high-density oligo tiling arrays including the $380 \mathrm{~K}$ (chromosome 22), the 2.1-M (Whole Genome) Nimblegen (Roche NimbleGen Systems, Reykjavik, Iceland), and the 240K (Chromosome 22) Agilent (Agilent Technologies, Inc., Santa Clara, CA, USA) arrays. These array analyses revealed that low amounts of template DNA do not result in a completely unbiased WGA but that stochastic amplification artifacts cause significant noise (Geigl et al., 2009). The platforms were validated using different cell lines and a new algorithm enabling the identification of small gains and losses in noisy ratio profiles was developed. They showed imbalances as small as $3.0 \mathrm{Mb}$ could be accurately detected using high resolution oligo arrays and concluded that probe density may have an important impact on the resolution limits (Geigl et al., 2009). To enhance the resolution further and reduce biases in the single cell amplification, we developed a single channel based normalization method to preprocess Agilent $244 \mathrm{~K}$ human mircroarray data (Cheng et al., 2011).

\section{CLINICAL USE OF OLIGO ARRAYS}

Hellani et al. (2008) reported the birth of the first baby after genome-wide aneuploidy screening of cleavage stage blastomeres using single cell oligo aCGH. Two blastomeres per biopsied embryo derived from eight couples suffering recurrent IVF failures were MDA amplified and analyzed on the Agilent Human Genome CGH 44B Oligo Microarray. The DNA from two blastomeres was pooled allowing for more reproducible data [data not shown (Hellani et al., 2008)]. Overall validation of the platform was limited (Hellani et al., 2008).

\section{SNP ARRAYS}

A different type of oligonucleotide arrays are SNP arrays targeting hundreds of thousands of SNPs. Single cell SNP-array analyses can detect copy number variations and disclose the genotype of the cell (Iwamoto et al., 2007; Vanneste et al., 2009a). Affymetrix (Affymetrix Inc., Santa Clara, CA, USA) and Illumina (San Diego, CA, USA) provide SNP arrays which differ by the number of probes and the SNP typing chemistry (such as the amplification technique, the number of color channels, the labeling procedure, and the time of the procedure). At first Affymetrix arrays targeted only 10,000 SNPs, but in their more recent product this further improved to $900 \mathrm{~K}$ SNPs supplemented with $900 \mathrm{~K}$ copy number probes (SNP 6.0 Array). Affymetrix arrays (Affymetrix Inc., Santa Clara, CA, USA) are based on a single color assay which is composed of multiple allele-specific probes that are complementary to SNP loci present in a reduced fraction of the genome. The reduced representation of the genome is achieved by digestion, adapter ligation, and PCR amplification. Following PCR-based amplification and fragmentation, the DNA is incorporated with biotin labeled nucleotides and hybridized onto the array. Following wash and scan, the signal intensity is quantified, and compared to intensities of normal individuals (such as HapMap individuals) in order to analyze the copy number. The total time for performing the assay is 4 days (Affymetrix Inc., Santa Clara, CA, USA) ${ }^{1}$. Illumina arrays (San Diego, CA, USA) are based on direct hybridization of whole genome-amplified genomic DNA (via a rolling circle replication mechanism) to a bead array of 50 mer locus-specific probes. These probes end one nucleotide before the SNP. Following hybridization each SNP is scored by a single base extension assay using differently labeled nucleotides. These labels are visualized by staining with an immunohistochemistry assay. For Illumina (San Diego, CA, USA) the first platform contained 317,000 probes and the newest 1 million SNP targets. The total time for performing the assay is 3 days (Illumina San Diego, CA, USA) $^{2}$, however Johnson et al. (2010) published a 24-h protocol.

\section{VALIDATION OF SNP ARRAYS}

Iwamoto and co-workers were the first to report single cell SNParray analyses for copy number detection using Affymetrix technology. They showed that variability in single cell amplification bias affected the genotype and copy number analysis of the cell severely (Iwamoto et al., 2007). Discordant genotypes were mainly localized close to centromeres or telomeres (Iwamoto et al., 2007). Single cell test WGA-samples could be successfully corrected for insufficiently amplified DNA regions by using both non-WGA and single cell WGA products as a reference for SNP-copy number calling (Iwamoto et al., 2007). Treff et al. (2011a) compared the PCR-based GenomePlex with the isothermal GenomiPhi and Repli-g MDA-WGA reaction for amplification reliability, fidelity and accuracy using the 250K NspI Affymetrix SNP microarray. The average genotyping coverage was $74 \%$ for GenomiPhi and $78 \%$ for Genomeplex, which where both significantly lower than the $88 \%$ obtained using Repli-g (Treff et al., 2011a). In our laboratory, an average coverage of $72 \%$ via the GenomiPhiV2 method was measured on the 250K NspI Affymetrix SNP (Vanneste et al., 2009a). Significant differences in the accuracy and copy number assignment exist amongst different single cell WGA methods (Treff et al., 2010, 2011a). Using the CNAT software (Affymetrix, Santa Clara, CA, USA) for single cell SNP-copy number typing, $62 \%$ of the SNPs had a match with the copy number profile of the genomic DNA sample extracted from many cells when the GenomiPhi method for single cell WGA was used. Copy number concordances of 95 and $99 \%$ were reached on the same SNPplatform when single cell genomes were amplified with Repli-G (Qiagen Inc., Valencia, CA 91355, USA) and GenomePlex (SigmaAldrich, St. Louis, MO 63103, USA) respectively (Treff et al., 2011a). Johnson et al. (2010) developed a new method for PGS, termed "parental support" which uses Illumina SNP microarray (CytoSNP-12 chips, San Diego, CA, USA) measurements from parental DNA to "clean" single cell microarray measurements on embryonic cells and explicitly computes confidence in each copy number call. A false-negative rate of $2.1 \%$ and a false-positive

\footnotetext{
${ }^{1}$ www.affymetrix.com

${ }^{2}$ www.illumina.com
} 
rate of $3.9 \%$ for copy number detection were estimated (Johnson et al., 2010). To detect segmental copy number aberrations their algorithm was applied to segments spanning one-fifth of a chromosome, limiting the ability to detect segmental abnormalities (Johnson et al., 2010). Handyside et al. (2010) developed a method enabling genome-wide linkage-based inheritance analysis of a broad range of genetic abnormalities including structural chromosomal abnormalities, DNA copy number variants as well as single gene defects identified as pre-existing in one or both parents using the Illumina Human CNV370 Infinium-II Quad and duo. They demonstrated that karyomapping is possible at the single cell level following MDA (Repli-G, Qiagen Inc., Valencia, CA 91355, USA) if only heterozygous informative loci are used (Handyside et al., 2010). We developed a novel algorithm that determines the allelic origin of (aberrant) loci by identifying and visualizing SNPs with a Mendelian error in a parent-specific manner at the genomewide level (Voet et al., 2011). Therefore, we genotyped both parents and the single blastomeres using Affymetrix 250K SNP arrays (Voet et al., 2011).

\section{CLINICAL USE OF SNP ARRAYS}

Schoolcraft et al. (2010) presented the first clinical application of blastocyst trophectoderm biopsy followed by SNP microarray based 24 chromosome aneuploidy screening, applied to 132 cases with advanced maternal age, recurrent pregnancy loss, or recurrent implantation failure. They achieved a clinical pregnancy rate of $77.8 \%$ (Schoolcraft et al., 2010). A case study by Brezina et al. (2011) reported the birth of a healthy child after combination of PGD using DNA sequencing, PCR linkage analysis for GM1 gangliosidosis mutations, and 23 chromosome aneuploidy detection following trophectoderm biopsy. For the aneuploidy screening they used MDA-WGA and Infinium high-density HumanCytoSNP-12 DNA analysis BeadChips (Illumina, San Diego, CA, USA). Treff et al. (2011b) presented a clinical prospective study using SNP-array-based translocation and 24 chromosome aneuploidy screening following trophectoderm biopsy. They first validated the ability to detect a priori known segmental aneusomies associated with unbalanced translocation inheritance. To this end, cells of FISH diagnosed unbalanced embryos were amplified by the GenomePlex WGA (SigmaAldrich, St. Louis, MO 63103, USA) and analyzed on the $250 \mathrm{~K}$ NspI SNP array (Affymetrix Inc., Santa Clara, CA, USA). They proved segmental aneusomies as small as $13.8 \mathrm{Mb}$ with as few as 908 SNP-probes could be identified in a single blastomere (Treff et al., 2011b).

\section{CONCLUSION AND FUTURE PROSPECTIVES}

The genome-wide detection of aneuploidies and segmental chromosomal imbalances in single cells can be accurately achieved by different array approaches. The accuracy has been established for different array platforms and the technologies are widely used to study human embryos. Nevertheless, the resolution remains well below the resolution obtained when using unamplified DNA on the same platforms. Further improvements in the resolution as well as the accuracy of single cell analyses are likely to come from further improvements in WGA methods, array platform design as well as algorithmic improvements.
Besides fundamental research questions, the main application of single cell array analysis in the clinic is PGD. PGD is typically performed on embryos from carriers of monogenic disorders or carriers of chromosomal rearrangements affecting the fertility (such as translocations or marker chromosomes). Currently chromosomal abnormalities are selected against using FISH, while monogenic disorders are diagnosed via PCR. Recently, single cell array techniques have been clinically implemented for PGD as well (Fishel et al., 2010; Alfarawati et al., 2011; Fiorentino et al., 2011; Treff et al., 2011b; Vanneste et al., 2011). Single cell microarray analysis could be envisioned as a novel generic diagnostic tool for PGD because it: (1) covers all 24 chromosomes, (2) makes the interpretation of the results more objective, and (3) excludes the family specific preparation compared to the current techniques.

In addition to PGD, PGS may be the prime clinical application. PGS is based on the hypothesis that selection of chromosomally normal embryos for uterine transfer can increase the live birth rate and decrease the spontaneous abortion rate per embryo transferred. Single cell array analysis allows genome-wide screening of de novo whole-chromosome and segmental imbalances in $24 \mathrm{~h}$ and can be performed on polar bodies, blastomeres, or trophectoderm cells. The widespread acceptance for PGS, however, will rely on the clinical validation, i.e., that this screening leads to increased baby-take-home-rates (Vanneste et al., 2009b; Geraedts et al., 2010; Harper et al., 2010a). The application of this technology is rapidly increasing (Harper et al., 2010b).

Whereas single cell BAC- and oligoarrays can be used to detect chromosomal imbalances, single cell SNP arrays may be used to find Mendelian disorders. The ability to genotype and haplotype single cells using SNP arrays has opened new avenues of single cell research. First, determining the haplotypes can strengthen the power and thus increase the resolution of single cell CNV detection (Vanneste et al., 2009a; Voet et al., 2011). Extracting the haplotypes enables the analysis of cross-over sites and the identification of copy number neutral abnormalities such as segmental uniparental disomy (UPD) as well as long contiguous stretches of homozygous SNPs (Kotzot, 2008). When parental genotypes are known as well, transmission of haplotypes can be measured. Simple haplotyping of SNPs surrounding and embedded in disease-causing genes allow the selection of embryos that have not inherited the affected risk allele (Harper and Harton, 2010). Genome-wide genotyping, may thus allow the selective transfer of genetically and chromosomally normal embryos for patients undergoing IVF with PGD for monogenic diseases (Handyside et al., 2010).

To understand the chromosomal instability in human embryos it may well be necessary to go beyond the inherent limitations of array CGH. With the strongly reduced costs of whole genome sequencing, those sequencing technologies offer the promise to further increase the resolution and provide the ultimate genomic architectural view of single cells for basic genome research purposes. It seems likely that the picture of human embryonic instability will become more complete in the years to come.

\section{ACKNOWLEDGMENTS}

We are grateful to Cindy Melotte for the critical reading of the manuscript. This work was made possible by grants from the IWT (SBO-60848; TBM-090878) and GOA/12/015 to Joris Robert 
Vermeesch and from the FWO-G.A093.11 and KUL PFV/10/016 SymBioSys to Joris Robert Vermeesch and Thierry Voet. Niels Van der Aa was supported by the FWO Flanders (FWO1.1.H28.12).
Evelyne Vanneste was supported by the Institute for the Promotion of Innovation through Science and Technology in Flanders (IWT-Vlaanderen).

\section{REFERENCES}

Alfarawati, S., Fragouli, E., Colls, P., and Wells, D. (2011). First births after preimplantation genetic diagnosis of structural chromosome abnormalities using comparative genomic hybridization and microarray analysis. Hum. Reprod. 26, 1560-1574.

Baart, E. B., Martini, E., van den Berg, I., Macklon, N. S., Galjaard, R. J., Fauser, B. C., and Van Opstal, D. (2006). Preimplantation genetic screening reveals a high incidence of aneuploidy and mosaicism in embryos from young women undergoing IVF. Hum. Reprod. 21, 223-233.

Blanco, L., Bernad, A., Lazaro, J. M., Martin, G., Garmendia, C., and Salas, M. (1989). Highly efficient DNA synthesis by the phage phi 29 DNA polymerase. Symmetrical mode of DNA replication. J. Biol. Chem. 264, 8935-8940.

Brezina, P. R., Benner, A., Rechitsky, S., Kuliev, A., Pomerantseva, E., Pauling, D., and Kearns, W. G. (2011). Single-gene testing combined with single nucleotide polymorphism microarray preimplantation genetic diagnosis for aneuploidy: a novel approach in optimizing pregnancy outcome. Fertil. Steril. 95, 1786 e5-1786 e8.

Cheng, J., Vanneste, E., Konings, P., Voet, T., Vermeesch, J. R., and Moreau, Y. (2011). Single-cell copy number variation detection. Genome Biol. 12, R80.

Daphnis, D. D., Fragouli, E., Economou, K., Jerkovic, S., Craft, I. L., Delhanty, J. D., and Harper, J. C. (2008). Analysis of the evolution of chromosome abnormalities in human embryos from day 3 to 5 using CGH and FISH. Mol. Hum. Reprod. 14, 117-125.

Fiegler, H., Carr, P., Douglas, E. J., Burford, D. C., Hunt, S., Scott, C. E., Smith, J., Vetrie, D., Gorman, P., Tomlinson, I. P., and Carter, N. P. (2003). DNA microarrays for comparative genomic hybridization based on DOP-PCR amplification of BAC and PAC clones. Genes Chromosomes Cancer 36, 361-374.

Fiegler, H., Geigl, J. B., Langer, S., Rigler, D., Porter, K., Unger, K., Carter, N. P., and Speicher, M. R. (2007). High resolution array-CGH analysis of single cells. Nucleic Acids Res. 35, e15.

Fiegler, H., Redon, R., Andrews, D., Scott, C., Andrews, R., Carder, C.,
Clark, R., Dovey, O., Ellis, P., Feuk, L., French, L., Hunt, P., Kalaitzopoulos, D., Larkin, J., Montgomery, L., Perry, G. H., Plumb, B. W., Porter, K., Rigby, R. E., Rigler, D., Valsesia, A., Langford, C., Humphray, S. J., Scherer, S. W., Lee, C., Hurles, M. E., and Carter, N. P. (2006). Accurate and reliable high-throughput detection of copy number variation in the human genome. Genome Res. 16, 1566-1574.

Fiorentino, F., Spizzichino, L., Bono, S., Biricik, A., Kokkali, G., Rienzi, L., Ubaldi, F. M., Iammarrone, E., Gordon, A., and Pantos, K. (2011). PGD for reciprocal and Robertsonian translocations using array comparative genomic hybridization. Hum. Reprod. 26, 1925-1935.

Fishel, S., Gordon, A., Lynch, C., Dowell, K., Ndukwe, G., Kelada, E., Thornton, S., Jenner, L., Cater, E., Brown, A., and Garcia-Bernardo, J. (2010). Live birth after polar body array comparative genomic hybridization prediction of embryo ploidy-the future of IVF? Fertil. Steril. 93, 1006 e7-1006 e10.

Geigl, J. B., Obenauf, A. C., WaldispuehlGeigl, J., Hoffmann, E. M., Auer, M., Hormann, M., Fischer, M., Trajanoski, Z., Schenk, M. A., Baumbusch, L. O., and Speicher, M. R. (2009). Identification of small gains and losses in single cells after whole genome amplification on tiling oligo arrays. Nucleic Acids Res. 37, e105.

Geraedts, J., Collins, J., Gianaroli, L., Goossens, V., Handyside, A., Harper, J., Montag, M., Repping, S., and Schmutzler, A. (2010). What next for preimplantation genetic screening? a polar body approach! Hum. Reprod. $25,575-577$.

Gutierrez-Mateo, C., Colls, P., SanchezGarcia, J., Escudero, T., Prates, R., Ketterson, K., Wells, D., and Munné, S. (2011). Validation of microarray comparative genomic hybridization for comprehensive chromosome analysis of embryos. Fertil. Steril. 95, 953-958.

Handyside, A. H., Harton, G. L., Mariani, B., Thornhill, A. R., Affara, N., Shaw, M. A., and Griffin, D. K. (2010). Karyomapping: a universal method for genome wide analysis of genetic disease based on mapping crossovers between parental haplotypes. J. Med. Genet. 47, 651-658.
Harper, J., Coonen, E., De Rycke, M., Fiorentino, F., Geraedts, J., Goossens, V., Harton, G., Moutou, C., Pehlivan Budak, T., Renwick, P., Sengupta, S. Traeger-Synodinos, J., and Vesela, K. (2010a). What next for preimplantation genetic screening (PGS)? A position statement from the ESHRE PGD consortium steering committee. Hum. Reprod. 25, 821-823.

Harper, J. C., Coonen, E., De Rycke, M., Harton, G., Moutou, C., Pehlivan, T., Traeger-Synodinos, J., Van Rij, M. C. and Goossens, V. (2010b). ESHRE PGD Consortium data collection $\mathrm{X}$ : cycles from January to December 2007 with pregnancy follow-up to october 2008. Hum. Reprod. 25, 2685-2707.

Harper, J. C., and Harton, G. (2010). The use of arrays in preimplantation genetic diagnosis and screening. Fertil. Steril. 94, 1173-1177.

Hellani, A., Abu-Amero, K., Azouri, J., and El-Akoum, S. (2008). Successful pregnancies after application of array-comparative genomic hybridization in PGS-aneuploidy screening. Reprod. Biomed. Online 17, 841-847.

Iwamoto, K., Bundo, M., Ueda, J., Nakano, Y., Ukai, W., Hashimoto, E., Saito, T., and Kato, T. (2007). Detection of chromosomal structural alterations in single cells by SNP arrays: a systematic survey of amplification bias and optimized workflow. PLoS ONE 2, e1306. doi:10.1371/journal.pone.0001306

Iwarsson, E., Lundqvist, M., Inzunza, J., Ahrlund-Richter, L., Sjoblom, P., Lundkvist, O., Simberg, N., Nordenskjöld, M., and Blennow, E. (1999). A high degree of aneuploidy in frozen-thawed human preimplantation embryos. Hum. Genet. 104 376-382.

Johnson, D. S., Gemelos, G., Baner, J., Ryan, A., Cinnioglu, C., Banjevic, M., Ross, R., Alper, M., Barrett, B., Frederick, J., Potter, D., Behr, B., and Rabinowitz, M. (2010). Preclinical validation of a microarray method for full molecular karyotyping of blastomeres in a 24-h protocol. Hum. Reprod. 25, 1066-1075.

Konings, P., Vanneste, E., Jackmaert, S., Ampe, M., Verbeke, G., Moreau, Y., Vermeesch, J. R., and Voet, T. (2012). Microarray analysis of copy number variation in single cells. Nat. Protoc. 7, 281-310.
Kotzot, D. (2008). Complex and segmental uniparental disomy updated. J. Med. Genet. 45, 545-546.

Le Caignec, C., Spits, C., Sermon, K., De Rycke, M., Thienpont, B., Debrock, S., Staessen, C., Moreau, Y., Fryns, J. P., Van Steirteghem, A., Liebaers, I., and Vermeesch, J. R. (2006). Singlecell chromosomal imbalances detection by array CGH. Nucleic Acids Res. 34, e68.

Munne, S., Sandalinas, M., Magli, C., Gianaroli, L., Cohen, J., and Warburton, D. (2004). Increased rate of aneuploid embryos in young women with previous aneuploid conceptions. Prenat. Diagn. 24, 638-643.

Oostlander, A. E., Meijer, G. A., and Ylstra, B. (2004). Microarray-based comparative genomic hybridization and its applications in human genetics. Clin. Genet. 66, 488-495.

Rius, M., Daina, G., Obradors, A., Ramos, L., Velilla, E., Fernandez, S., Martínez-Passarell, O., Benet, J., and Navarro, J. (2011). Comprehensive embryo analysis of advanced maternal age-related aneuploidies and mosaicism by short comparative genomic hybridization. Fertil. Steril. 95, 413-416.

Rubio, C., Simon, C., Vidal, F., Rodrigo, L., Pehlivan, T., Remohi, J., and Pellicer, A. (2003). Chromosomal abnormalities and embryo development in recurrent miscarriage couples. Hum. Reprod. 18, 182-188.

Saunders, R. D., Glover, D. M., Ashburner, M., Siden-Kiamos, I., Louis, C., Monastirioti, M., Savakis, C., and Kafatos, F. (1989). CR amplification of DNA microdissected from a single polytene chromosome band: a comparison with conventional microcloning. Nucleic Acids Res. 17, 9027-9037.

Schoolcraft, W., Treff, N., Ferry, K., Stevens, J., Katz-Jaffe, M., and Scott, R. (2010). First clinical application of SNP microarray based 24 chromosome aneuploidy screening of human blastocysts. Fertil. Steril. 94, S23-S24.

Sermon, K., Lissens, W., Joris, H., Van Steirteghem, A., and Liebaers, I. (1996). Adaptation of the primer extension preamplification (PEP) reaction for preimplantation diagnosis: single blastomere analysis using short PEP protocols. Mol. Hum. Reprod. 2, 209-212. 
Shearer, B. M., Thorland, E. C., Gonzales, P. R., and Ketterling, R. P. (2007). Evaluation of a commercially available focused aCGH platform for the detection of constitutional chromosome anomalies. Am. J. Med. Genet. A 143A, 2357-2370.

Spits, C., Le Caignec, C., De Rycke, M., Van Haute, L., Van Steirteghem, A., Liebaers, I., and Sermon, K. (2006a). Whole-genome multiple displacement amplification from single cells. Nat. Protoc. 1, 1965-1970.

Spits, C., Le Caignec, C., De Rycke, M., Van Haute, L., Van Steirteghem, A., Liebaers, I., and Sermon, K. (2006b). Optimization and evaluation of single-cell whole-genome multiple displacement amplification. Hum. Mutat. 27, 496-503.

Spits, C., and Sermon, K. (2009). PGD for monogenic disorders: aspects of molecular biology. Prenat. Diagn. 29, 50-56.

Treff, N. R., Su, J., Tao, X., Levy, B., and Scott, R. T. Jr. (2010). Accurate single cell 24 chromosome aneuploidy screening using whole genome amplification and single nucleotide polymorphism microarrays. Fertil. Steril. 94, 2017-2021.

Treff, N. R., Su, J., Tao, X., Northrop, L. E., and Scott, R. T. Jr. (2011a). Singlecell whole-genome amplification technique impacts the accuracy of SNP microarray-based genotyping and copy number analyses. Mol. Hum. Reprod. 17, 335-343.

Treff, N. R., Northrop, L. E., Kasabwala, K., Su, J., Levy, B., and Scott, R. T. Jr. (2011b). Single nucleotide polymorphism microarray-based concurrent screening of 24-chromosome aneuploidy and unbalanced translocations in preimplantation human embryos. Fertil. Steril. 95, 1606-12 e1-1606-12 e2.

Vanneste, E., Melotte, C., Voet, T., Robberecht, C., Debrock, S., Pexsters, A., Staessen, C., Tomassetti, C., Legius, E., D'Hooghe, T., and Vermeesch, J. R. (2011). PGD for a complex chromosomal rearrangement by array comparative genomic hybridization. Hum. Reprod. 26, 941-949.

Vanneste, E., Voet, T., Le Caignec, C. Ampe, M., Konings, P., Melotte, C., Debrock, S., Amyere, M., Vikkula, M., Schuit, F., Fryns, J. P., Verbeke, G., D’Hooghe, T., Moreau, Y., Vermeesch, J. R. (2009a). Chromosome instability is common in human cleavage-stage embryos. Nat. Med. 15, 577-583.

Vanneste, E., Voet, T., Melotte, C., Debrock, S., Sermon, K., Staessen, C., Liebaers, I., Fryns, J. P., D’Hooghe, T., and Vermeesch, J. R. (2009b). What next for preimplantation genetic screening? High mitotic chromosome instability rate provides the biological basis for the low success rate. Hum. Reprod. 24, 2679-2682.

Vermeesch, J. R., Fiegler, H., de Leeuw, N., Szuhai, K., Schoumans, J., Ciccone, R., Speleman, F., Rauch, A., Clayton-Smith, J., Van Ravenswaaij, C., Sanlaville, D., Patsalis, P. C., Firth, H., Devriendt, K., and Zuffardi,
O. (2007). Guidelines for molecular karyotyping in constitutional genetic diagnosis. Eur. J. Hum. Genet. 15, 1105-1114.

Voet, T., Vanneste, E., Peeters, H., Konings, P., Fryns, J., D'Hooghe, T., Moreau, Y., and Vermeesch, J. (2009). Haplotyping of Single Human Cells: Chromosome Research. Springer: Dordrecht, 106.

Voet, T., Vanneste, E., Van der Aa, N. Melotte, C., Jackmaert, S., Vandendael, T., Declercq, M., Debrock, S. Fryns, J. P., Moreau, Y., D'Hooghe, T., and Vermeesch, J. R. (2011). Breakage-fusion-bridge cycles leading to inv dup del occur in human cleavage stage embryos. Hum. Mutat. 32, 783-793.

Voullaire, L., Slater, H., Williamson, R. and Wilton, L. (2000). Chromosome analysis of blastomeres from human embryos by using comparative genomic hybridization. Hum. Genet. 106, 210-217.

Voullaire, L., Wilton, L., McBain, J., Callaghan, T., and Williamson, R. (2002). Chromosome abnormalities identified by comparative genomic hybridization in embryos from women with repeated implantation failure. Mol. Hum. Reprod. 8, 1035-1041.

Wells, D., and Delhanty, J. D. (2000). Comprehensive chromosomal analysis of human preimplantation embryos using whole genome amplification and single cell comparative genomic hybridization. Mol. Hum. Reprod. 6, 1055-1062.
Wilton, L. (2005). Preimplantation genetic diagnosis and chromosome analysis of blastomeres using comparative genomic hybridization. Hum. Reprod. Update 11, 33-41.

Zhang, L., Cui, X., Schmitt, K., Hubert, R., Navidi, W., and Arnheim, N. (1992). Whole genome amplification from a single cell: implications for genetic analysis. Proc. Natl. Acad. Sci. U.S.A. 89, 5847-5851.

Conflict of Interest Statement: The authors declare that the research was conducted in the absence of any commercial or financial relationships that could be construed as a potential conflict of interest.

Received: 01 December 2011; paper pending published: 14 December 2011; accepted: 12 March 2012; published online: 27 March 2012.

Citation: Vanneste E, Bittman L, Van der Aa N, Voet T and Vermeesch JR (2012) New array approaches to explore single cells genomes. Front. Gene. 3:44. doi: 10.3389/fgene.2012.00044

This article was submitted to Frontiers in Epigenomics, a specialty of Frontiers in Genetics.

Copyright (C) 2012 Vanneste, Bittman, Van der Aa, Voet and Vermeesch. This is an open-access article distributed under the terms of the Creative Commons Attribution Non Commercial License, which permits non-commercial use, distribution, and reproduction in other forums, provided the original authors and source are credited. 